\title{
Estimation of pesticide residues in table grapes by using gas and liquid chromatography coupled with mass spectrometry
}

\author{
S.P. Yadav ${ }^{1 *}$, B.K. Singh ${ }^{2}$, Rakesh Pandey², A.K. Singh'², M.K. Mishra ${ }^{2}$ and S.K. Singh ${ }^{2}$ \\ ${ }^{1}$ National Horticultural Research and Development Foundation, Nasik (M.S.) India \\ ${ }^{2}$ Department of Entomology, Banda University of Agriculture and Technology, Banda (U.P.) India
}

\section{ARITCLE INFO}

Received : 17.01 .2020

Revised : 25.02 .2020

Accepted : 10.03 .2020

KEY WORDS :

GC-MS/MS, grapes, LC-MS/MS,

MRL, Pesticide residues analysis

\begin{abstract}
The grapes are being exported in increasing quantities from Maharashtra to European countries and a lot of pesticide inputs are being used by the growers. A total number of 578 grape samples collected from Nasik district during December, 2013 to April, 2014 and analyzed for 167 numbers of multi-class pesticide (Organophosphate, Triazine, Pyrimidine, Triazole, Imidazole, Benzimidazole, Nicotinoid, Substituted thiourea, Strobiluron, Dinitroaniline, Morpholine) residue levels using Liquid ChromatographyMass spectrometry/Mass spectrometry (LC-MS/MS) and Gas Chromatography-Mass spectrometry/Mass spectrometry (GC-MS/MS) by using validated methods. Only four samples were free from pesticide residues and rest were contaminated with 1-13 numbers of pesticides residue. During the study different classes of total 41 number of agrochemicals had been detected and 116 number of samples were failed with residues of 4Bromo-2-Chlorophenol, Abamectin, Carbendazim, Chlormequat Chloride, Chloropyriphos, Dinocap, Forchlorfenuron, Hexaconazole, Flusilazole, Profenophos, Spinosad, Thiacloprid, Triazophos, Fipronil and Acephate by exceeding their European Union MRLs.

How to view point the article : Yadav, S.P., Singh, B.K., Pandey, Rakesh, Singh, A.K., Mishra, M.K. and Singh, S.K. (2020). Estimation of pesticide residues in table grapes by using gas and liquid chromatography coupled with mass spectrometry. Internat. J. Plant Protec., 13(1) : 50-57, DOI : 10.15740/HAS/IJPP/13.1/50-57, Copyright@ 2020: Hind Agri-Horticultural Society.
\end{abstract}

